This is an electronic reprint of the original article. This reprint may differ from the original in pagination and typographic detail.

Author(s): Luoma, Mikko; Risikko, Tanja; Erkkilä, Paula

Title: $\quad$ Strategic choices of Finnish universities in the light of general strategy frameworks

Year: $\quad 2016$

Version:

Please cite the original version:

Luoma, M., Risikko, T., \& Erkkilä, P. (2016). Strategic choices of Finnish universities in the light of general strategy frameworks. European Journal of Higher Education, 6(4), 343-355. https://doi.org/10.1080/21568235.2016.1224672

All material supplied via JYX is protected by copyright and other intellectual property rights, and duplication or sale of all or part of any of the repository collections is not permitted, except that material may be duplicated by you for your research use or educational purposes in electronic or print form. You must obtain permission for any other use. Electronic or print copies may not be offered, whether for sale or otherwise to anyone who is not an authorised user. 


\title{
Strategic Choices of Finnish Universities in the Light of General Strategy Frameworks
}

\begin{abstract}
This study examines university strategies from the content perspective. Since the early 1980s, the pressure to adopt strategic management in universities and other higher education institutions has increased because of issues including reduced public funding, pressures and possibilities for internationalisation, developments in teaching technologies, and demands for increased accountability to stakeholders. The study employs content analysis and multivariate statistical techniques to examine the written strategies of 13 Finnish universities formulated after the University Act 2010 that aimed at enhancing their competitiveness in the global arena. The studied organisations cover practically Finland's entire university sector. As a novel tool, the study introduces visual presentations of strategy and investigates to what degree the strategies conform to general content strategy frameworks, such as generic competitive strategies, strategic types, and value disciplines. The results indicate only light conformity with such frameworks. Finally, the study discusses the implications of these findings for both researchers and practitioners of management in the higher education sector.
\end{abstract}

Keywords: Strategy, strategic choices, visual mapping, content analysis, multidimensional scaling 


\section{STRATEGIC CHOICES OF FINNISH UNIVERSITIES IN THE LIGHT OF GENERAL STRATEGY FRAMEWORKS}

\section{Introduction}

Strategic management as a concept and practice has established itself in many types of organisations in recent decades. Certainly, that development is largely due to increased managerial awareness and to the intensive research and development of management theories and tools, all of which have been significantly influenced by work done in higher education institutions. Against this background, it is somewhat paradoxical to note that higher education institutions have themselves been slow to adopt the practices of strategic management in their own management work (Keller, 1983; Kotler and Murphy, 1981; Tirronen, 2014; Wyrwa, 2012).

The pressure for more intensive use of strategic management has been widely addressed and debated in higher education institutions in the US, Europe, and elsewhere since the 1980s. Scholars (e.g. Rolfe, 2003; Rowley, Lujan and Dolence, 1997; Shattock, 2000; de Zilwa, 2010) have explained this development by reference to external factors, such as reduced public funding, the pressures for internationalisation, newly available teaching and other technologies, increased accountability to stakeholders, and the widespread use of rankings. In the context of Finnish universities, from where the empirical material of this article originates, the adaptation of strategic management is strongly associated with the latest phase of national university reform, namely the legislative change that addresses a clear shift of decision making authority from the state to the universities (Tirronen, 2014).

The pronounced position of strategic management leads one to address not only how universities and other higher education institutions now conduct their processes of strategic management (the process perspective), but also and in particular what is the nature of the strategies they pursue (the content perspective). This article focuses on the second of these fundamental perspectives on strategic management (de Wit and Meyer, 2004), and delves into the content of strategies by identifying the core themes that the studied universities portray as their most important strategic choices.

Because there is, to the best knowledge of the authors, no generally recognised theory encapsulating the content of university strategies as compared to the content of strategies generally, the study investigates with nation-wide strategy material to which degree the intended strategies of universities conform to the general content strategy frameworks that are said to explain the differences between actors (competitors) in any industry. In examining these general frameworks, this study identifies and utilises the following: generic competitive strategies (Porter, 1980), strategic types (Miles and Snow, 1978), and value disciplines (Treacy and Wiersema, 
1993). The empirical content of the study is derived from authentic strategy documents, and they are assumed to be valid reflections of the focal institutions' intentions and choices and to adequately capture how institutions intend to proceed in the changing operating environment.

The study starts by first reviewing the literature on university strategies, particularly from the content perspective. Subsequently, it outlines the basic ideas of the frameworks as mentioned above and then reports on an empirical study of Finnish universities' strategies. The study then presents conclusions on the potential correspondence between the strategies of actors within the 'higher education industry' and the general frameworks. Finally, the study discusses the implications of the findings for both researchers and practitioners working in higher education management.

\section{What is known about the Content of University Strategies?}

As mentioned above, the call for university strategies started to intensify in management literature in the early 1980s. Kotler and Murphy (1981) were among the first to address the importance of strategies in universities and colleges, and their study promotes the idea of an organisation developing and maintaining a strategic fit with its changing marketing opportunities. Soon, Keller (1983) continued with an exhaustive analysis of the changing operating environment of US universities and, like Kotler and Murphy (1981), proposed a model for universities to apply when building high-quality strategies. At the same time, Shirley (1983) introduced his idea of four necessary levels of strategy in higher education institutions to contrast with the three levels of strategy typically identified in the for-profit corporate context (Vancil and Lorange, 1975). It is interesting to note that only Keller (1983) among these early advocates of university strategies offered any explicit framework of strategy content by referring to the need to select between the generic competitive strategies presented by Porter (1980).

Like strategy literature in general, the presentations on university strategies can be divided into two groups owing to their tendency to emphasise either some individual aspect of the overall strategy or the holistic content of strategy. In the former cases, the authors of such presentations, directly or indirectly, indicate the paramount importance of the aspect in question over other content-related aspects. These aspects then play themselves out as necessary strategic directions required of the universities. The most commonly emphasised individual aspects of this type are: internationalisation (Callan, 2000; Elkin, Farnsworth, and Templer, 2008), marketing and brand building (Hemsley-Brown and Oplatka, 2006; Ivy, 2001), technology management (Daniel, 1996), and knowledge and human resource management (Brewer and Brewer, 2010). Despite the popularity of this partial view of strategy, it has limited value for this study, because the grouping of institutions into homogenous groups based on their strategic intentions requires information on holistic strategies, as will be demonstrated below. Instead, this study will focus on the latter group 
of strategies, namely the holistic presentations that enable several strategic choices, any of which can lead to successful outcomes according to their developers.

Regarding these holistic strategy presentations, the literature on university strategies appears to favour conceptual and normative presentations over empirical studies. However, there are some interesting exceptions. Conway, Mackay, and Yorke (1994), building on the ideas of Shirley (1983), analysed the mission statements of 83 higher education institutions in the UK and found that the mission statements reflected the institutions' strategic orientation towards product marketing, service marketing or customer group-related viewpoints. Morphew and Hartley (2006) also conducted an analysis of the mission statements of 299 US higher education institutions from different categories of Carnegie Classification and found how certain themes (such as 'serves local area', 'liberal arts', and 'commitment to diversity') appeared in them across the institution types. They suggested that more research should be directed to investigating institutions emphasising similar themes (i.e. institutions that appear to favour similar strategic choices) regardless of their formal category.

Another strand of empirical research on the content of strategies is the investigation of what kind of strategies universities use as responses to the forces of the environment. Mouwen (2000) analysed the nature of changing operating environment and relative shares of public and marketrelated budgets of Dutch universities and outlined three alternative strategies and structural choices for the universities, the most viable of which emphasises the synergy between the traditional task and new market activities. Rolfe (2003) interviewed 33 university senior managers to investigate changes in university strategies following the introduction of tuition fees in the UK. She found out that the most typical strategic responses were related to increased attention to financial management (cost reduction and income generation), quality (of both inputs and outputs), and marketing. De Zilwa (2005) studied the response of Australian universities to reduced public funding and used the amount and sources of independent revenue as measures of entrepreneurialism adopted by the universities. She concluded that some (albeit too little) strategic differentiation between the universities occurred and recommended more corporate-type networking (with agents, competitors and partners) as well as embracing innovation and risktaking.

Mintzberg and Rose (2003) made a unique contribution to the content studies of university strategies in tracking the realised strategies of McGill University between 1829 and 1980 and concluded that the amount of change in top down driven strategy had been modest during the 150year period.

Focusing on the behaviour of those in management positions, the longitudinal study of Jarzabkowski (2008) also shed light on the content of university strategies. She identified how the overall strategies of some UK universities accorded with four content areas (that did not 
necessarily appear as 'official' sub-strategies of the studied institutions), namely research, teaching, commercial income, and size-and-scope areas. Her analysis of three in-depth cases over seven years concluded that the universities' progress in only one of the content areas-commercial income- - had been successful, whereas the other three had produced both successful and unsuccessful outcomes across the cases.

Jarzabkowski was also among the first researchers to apply the so-called strategy as practice perspective to university management. Building largely on her work, Tirronen (2014) points out how, especially in the context of the university reform, it is useful to see strategic management in universities as a holistic phenomenon that is present in, shapes and gets shaped by a countless number of daily activities of different actors. These can be characterised as specific 'goal-seeking behaviours' (Jarzabkowski and Wilson, 2002) and they are supported by relatively stable organisational practices that occur, for example, in the context of the centralised administration and strong departments typical of universities. This line of theorising views the content of universities' strategies in a different way to the more formal approaches discussed earlier and actually places little emphasis on mere strategy outcomes (such as mission and vision statements or implementation plans) without the profound consideration of the context and the process at the same time. Earlier, Hardy (1991) had adopted the same approach by showing how the content of universities' strategies is shaped and implemented through the various practices in the universities' overall stream of actions.

In the context of Finnish universities, Ursin, Aittola, Henderson, and Välimaa (2010) used the authentic strategy material of a number of universities to investigate the universities' motivation to form three major mergers that significantly affected the structure of the national university sector. They found that the majority of strategy and other planning documents focused on administrative and research issues as their main content themes, particularly at the expense of educational issues.

What can be concluded from these strategy content studies? At least that they appear to outline the strategic choices of the studied higher education institutions differently, without any common framework to date. On the other hand, as long as the institution-level challenges affected by the changing operating environment and the political expectations for sector-wide reforms prevail, the pressure to adopt the models of strategic management in universities will continue.

It has been suggested that well-established strategy tools from the corporate world should be increasingly applied in the university sector, while taking into account the special characteristics of universities absent from business organisations (Wyrwa, 2012). The strategy tools that this study focuses on include the following: generic competitive strategies (Porter, 1980), strategic types (Miles and Snow, 1978) and value disciplines (Treacy and Wiersema, 1993). These frameworks will be discussed briefly in the following section, before the study moves on to investigate their applicability and potential value in the university sector. 


\section{General Content Frameworks of Strategies}

Interest in the content of strategies has certainly existed in some form since the inception of strategic management as an academic discipline, but the active development of the content perspective only started after the mid-1970s. For example, in a comprehensive review, Hofer (1975) described how the process perspective had been emphasised at the expense of the content. Since then, several developments have occurred.

Fahey and Christensen (1986) and later Montgomery, Wernerfelt, and Balakrishnan (1989) outlined the domain of content decisions by separating the aspects related to 1) goals, 2) scope, and 3) ways of competing. Collis and Rukstad (2008) demonstrated the viability of this trinity in their more recent text on the critical components of strategy.

Alongside the endeavour to clarify the necessary content components of strategy, a more influential line of theorising has arisen in the creation of strategy typologies that render different strategic choices apparent and manageable. Hambrick (1984) noted that some classification system is needed to study organisational strategies because of the large number of potential variables involved. Two basic types of typologies can be identified. First, there are empirically derived taxonomies, such as those created by Galbraith and Schendel (1983) and Hawes and Crittenden (1984) that aim to identify an internal order (a limited number of different strategies) from a set of predefined strategic measures. Second, and more popular, are strategy typologies that are not based on any specific empirical sample and that are considered to be generic in nature, that is, strategy typologies that are applicable throughout different industries and economic cycles. The best-known examples of such typologies include those created by Miles and Snow (1978), Porter (1980), and Treacy and Wiersema (1993).

This study utilises the mentioned works as its reference basis and refers to them as general strategy frameworks. The term general relates to the view that none of these frameworks is expressly stated by their developers to be inapplicable to certain industries or sectors, and because they have been applied empirically to various organisational environments also outside of the business context. However, as the literature review establishes, their direct application to the study of strategic management in higher education institutions is limited.

Each of the general strategy frameworks mentioned is a rich collection of ideas and would merit a thorough presentation of its origins and internal dynamics. However, owing to limited space and extensive awareness of the frameworks among the management audience, only the key terms referring to the content areas identified in each framework will be listed here. All these frameworks outline a small number of fundamentally different strategic choices available to the 
organisations within the same industry. Strategic types (Miles and Snow, 1978) include the basic alternatives of Defender, Prospector, Analyser, and Reactor; generic strategies (Porter, 1980) include the choices of cost leadership, differentiation, and focus (and implicitly 'stuck in the middle'); and value disciplines (Treacy and Wiersema, 1993) include options orientated towards operational excellence, product leadership, and customer intimacy.

At the end of the following empirical study, the endogenously identified strategy content areas will be contrasted with the general strategy frameworks and their content alternatives.

\section{Research Context, Material and Methods}

Universities in Finland have undergone several government-initiated changes since the year 2000, examples of which include the definition of the third mission of universities to serve their larger societal environment, the implementation of a performance-related pay system, the implementation of a system for time management, and the adaptation of complex systems of quality control (Rinne, 2004; Kauppinen and Kaidesoja, 2014). A comprehensive change in the governance of universities took place following the new University Act of 2010, which extended their autonomous decision making and encouraged the recruitment of external actors, particularly from the corporate world, to their Boards of Directors. It is a moot point whether these changes are part of one major reform or individual reforms in themselves (Ursin and Välimaa, 2012).

The data were collected in July 2013 from strategy documents produced by Finnish universities, which are publically available, most often from the university's website. In most cases, the publicly available strategy document was clearly marked as being the one that the university's Board of Directors had officially approved, and if that was not expressly mentioned, the official strategy was requested directly from the university's administration. The strategy information remains accessible because Finnish universities are still considered public institutions. Of the 15 universities in Finland, the strategy documents of two institutions were excluded from the study. One (the National Defence University) has a special purpose and does not operate under the auspices of the Ministry of Education and Culture as the other universities do, and the other (the University of Arts) had just been formed as a result of a merger and did not have any overall strategy in place at the time of data collection. All the collected strategies had been formulated in the same period after the passage of the University Act and they typically covered the time period of the following four to five years, and were therefore considered to be valid presentations of the universities' future directions in the new context. Three of the studied universities (Aalto University, the University of Eastern Finland and the University of Turku) had undergone significant structural changes following the amendment of the legislation and their strategies represented not only their managements' views on how best to succeed under the present 
circumstances, but also constituted the very first future guidelines for the new organisational entities.

Content analysis was employed to study the strategies. From each strategy document (presented in Finnish, Swedish, and/or English), individual keywords (nouns, verbs or adjectives) conveying essential information were identified. Examples of keywords included: society, research and teaching infrastructure, quality, international students, executive education, networking, and tenure track. Altogether 133 different keywords were received in this phase. Terms that referred to individual sciences, disciplines or subjects were not included among the keywords, because the emphasis was on institutional level strategies (see Shirley, 1983). Applying this limitation also avoided an interpretation problem, because some terms, such as finance or pedagogy, may refer either to a discipline or a functional area of the university, and, would therefore have required a dual coding. In practice, the keywords listed acted as understandable summaries of each strategy and studying them presented a coherent idea of the issues that the university in question sought to emphasise.

Synonymous or logically interconnected keywords were then grouped into internally homogenous groups, resulting in 38 keyword groups, each of which includes from one to ten individual keywords. Each of the above-mentioned phases of content analysis was conducted manually.

During the first phase (collection of the keywords), the frequencies of each keyword in each university's strategy document had been marked. The frequencies of individual keywords within the same keyword group were summed to record how many times each keyword group appeared in each university's strategy document. Then, the absolute frequencies were transformed into relative frequencies to ensure comparability across the universities. Examining the total relative frequencies of all keyword groups for further phases of the study led to the 13 most frequently emphasised keyword groups being identified. Those 13 groups accounted for $66 \%$ of all the content information collected, which was considered to permit a reliable statistical analysis in the next phases. Adding the next keyword group would have increased the quality of the solution only marginally.

Knowing the importance of each keyword group in each university's strategy, made it possible to apply the multidimensional scaling (MDS) algorithm, multidimensional preference scaling (MDPREF), which utilises preference data (scores or ranks) from several subjects to build a visual solution in which equally preferred objects are located close to each other in a multidimensional space (for details on the method see, Chang and Carroll, 1969; Kruskal and Wish, 1978). In this study, keyword groups were used as objects and universities served as subjects. MDS is relatively widely used in areas like information sciences and psychometrics but apparently has not been applied in the study of strategic management; consequently, this study aims to make a methodological contribution. 
The next phase employed hierarchical cluster analysis to form meaningful clusters of both keyword groups and universities based on their location in a multidimensional space. The solution of four strategy content areas (containing a varying number of individual keyword groups) appeared the most stable and, therefore, was selected as the basis for comparison with the general strategy frameworks. Accordingly, the universities were organised into four distinct clusters based on their tendency to emphasise various elements of strategy similarly (make similar strategic choices) within the clusters and differently between the clusters, so as to provide a visual MDPREF solution (see Figure 1).

[Figure 1 near here]

\section{Strategy Content Areas and General Strategy Frameworks}

The strategy content areas identified via the procedures mentioned above are as follows. The descriptive titles are adapted from the individual keywords and keyword groups they contain.

- Strategy content area 1: Diverse, ethical, and valued member of society;

- Strategy content area 2: Internationalism;

- Strategy content area 3: Economy and internal processes;

- Strategy content area 4: Networking.

As a whole, this listing of endogenously derived content areas of universities' strategies bears little resemblance to any of the general strategy frameworks. The most similar content areas and components of general frameworks are economy and internal processes in this study and the cost leadership of Porter (1980) and the operational excellence of Treacy and Wiersema (1993). Specifically, the focus on new knowledge and innovation in the content area economy and internal processes separates it from the general frameworks. Strategy content areas 1, 2 and 4 in this study are clearly externally orientated but do not match with the externally-orientated alternatives of prospector of Miles and Snow (1978) or customer intimacy of Treacy and Wiersema (1993), which are predicated on either active seeking of new markets and/or technologies or the unceasing attempt to tailor products/services to meet the needs of a carefully identified market segment, which are not represented in the content areas of this study.

In addition to the comparison of individual strategy content areas with the components of generic frameworks, using the analysis of variance (ANOVA) and related post-hoc tests, the study investigated whether the overall profiles of the university clusters (also marked in Figure 1) differed from each other and would, as holistic combinations of content areas, correspond to various general strategy profiles. 
The tests showed significant differences (at the 0.05 level) between the university clusters in some individual content areas: University cluster 2 encompassing two multidisciplinary institutions emphasises being a diverse, ethical, and valued member of society more than university clusters 1 and 4 , and networking less than university cluster 4 . The emphasis on economy and internal processes and internationalism did not differ between the clusters. Post-hoc tests were not applicable to university cluster 3 , as this cluster comprised only one university. The ANOVA results are presented in Table 1.

[Table 1 near here]

ANOVA and post-hoc tests did not bring to light any new interpretation of the potential similarities between the endogenously derived strategic choices and the general strategy frameworks. The conclusion is that there are some differences in strategy content areas between the universities; however, the resulting strategy profiles do not conform substantially to any general strategy framework.

\section{Implications for Theory and Practice}

The results indicate that there are minor differences between the overall strategic choices of Finnish universities, and that those do not relate significantly to the best-known content frameworks of strategic management. The findings give rise to a number of implications for both theory and practice.

With reference to the discussion on the renewal of the higher education sector in Finland, the Nordic countries, and Europe in particular, the findings of this article indicate that strategic management in universities is not as important a vehicle for renewal as the models and the experience from the corporate world suggest. In the studied Finnish context, the pressure for universities to adopt more intensive forms of strategic management comes mainly from the policy making bodies, particularly from the ministry, and not from the universities themselves. This is a major difference compared to the evolution of strategic management in business organisations, where the drive to seek new ways of managing themselves is assumed to mainly emerge from the organisations' internal motivation. In a conceptual examination of the management of higher education reforms, Välimaa (2013) makes a distinction between the initiators and the objects of the reforms, and notes that the objectives of the former may differ radically from those of the latter. Likewise, the assessment of the results of such reforms is complicated because of this multitude of objectives and the presence of 'unwanted' results that always follow from the reforms (Välimaa, 2013). The question of the extent to which strategic management is also a desired result of the objects - the universities - would be an interesting topic of further research. 
In order to understand the current nature of strategic management in Finnish universities, one needs to understand the historical evolution of the higher education sector in the nation, particularly its role as a contributor to the development of the Finnish 'welfare society' (Diogo, 2015; Marginson, 2012; Ursin and Välimaa, 2012). Finnish universities have served the needs defined by society and the degree of autonomy assigned to the universities has resembled more a gift from society than their general prerogative. It follows that the function of strategic management has traditionally been to satisfy the multiple interests of society and the needs of the institution and its departments. When autonomy is suddenly increased, a university may find itself in a situation with fewer rather than more aspirations as the 'compulsory' role of the societal needs becomes distant and the resulting strategies may thus be poorer, which is counter to the original expectations of those who initiated the reform. This logic is brought up by Koryakina, Sarrico, and Teixeira (2015) as one potential development path following higher education reform. The research setting of this study does not allow the comparison of previous and current strategies, but the apparent emphasis on societal issues in the studied strategies may well indicate the lack of other, novel choices.

With regard to strategic management theory, the results cast doubt on the generalisability of the general strategy frameworks. The idea of generic strategy models that would be applicable across industries and sectors is appealing and widely used, but could not explain the choices of the institutions of this study. It is not claimed however that generalisability in terms of strategy content would never exist in any form, but researchers would be wise to acknowledge the limitations of the research settings where the content frameworks are applied. Neither should the content areas identified in this study be seen as offering an alternative to generic strategy components - not even in the higher education sector - since they are derived from one specific national and situational setting. Generalisability is possible, but always within limits, and these limits should always be made explicit when strategy content frameworks are applied.

Another implication relating to theory development arises from the study addressing the need and opportunity to access the authentic strategy material of universities and other higher education institutions to discern their future (or past) intentions. The current research views the official strategy documents as manifestations of universities' strategic choices, which proved to be a productive approach. The earlier empirical studies have largely ignored such formal strategic presentations and favoured indirect and partial measures, such as budget figures and individuals' perceptions, as indicators of institutions' strategic choices. It is unlikely that documents alone could convey all the information required to understand the overall progress of an institution, but certainly, the exclusion of the direct manifestations of the strategy content creates a problem that cannot be eliminated by a reliance on other sources of information. 
The present study also makes a methodological contribution by presenting a means to convert textual strategy information into a visual form that enables the comparison of different independent subjects. The combined use of content analysis, MDS techniques, and cluster analysis is an example of a methodology that bridges the gap between qualitative and quantitative research, which are typically seen as separate poles in organisational research.

For practitioners of strategic management in higher education institutions, this study underlines the importance of distinctive choices that challenge the traditional success factors of the sector. The findings suggest there is ample potential for differentiation, the discovery of which would be valuable as the competition for funding, students, and personnel looks set to intensify in the future. It is both paradoxical and alarming that the search for new sources of differentiation often starts by applying the same general strategy frameworks whose value in the university sector the current study indicates is minimal. Strategy makers in universities are therefore advised not to restrict themselves to the frameworks that have become dominant elsewhere-especially in the private sector-as they strive to renew their organisations and the entire higher education sector. 


\section{References}

Brewer, P. D., and K. L. Brewer. 2010. "Knowledge Management, Human Resource Management, and Higher Education: A Theoretical Model.” Journal of Education for Business 85: 330-335.

Callan, H. 2000. “The International Vision in Practice: A Decade of Evolution.” Higher Education in Europe XXV (1): 15-23.

Chang, J. J., and J. D. Carroll. 1969. How to Use MDPREF, a Computer Program for Multidimensional Analysis of Preference Data. Unpublished paper. Murray Hill, NJ: Bell Laboratories.

Collis, D. J., and M. G. Rukstad. 2008. “Can You Say What Your Strategy Is?” Harvard Business Review April: 82-90.

Conway, T., S. Mackay, and D. Yorke. 1994. "Strategic Planning in Higher Education: Who Are the Customers?” International Journal of Educational Management 8 (6): 29-36.

Daniel, J. S. 1996. Mega-Universities \& Knowledge Media: Technology Strategies for Higher Education. Abingdon: Routledge.

De Wit, B., and R. Meyer. 2004. Strategy: Process, Content, Context. London: Thomson International Business Press.

De Zilwa, D. 2005. "Using Entrepreneurial Activities as a Means of Survival: Investigating the Processes Used by Australian Universities to Diversify Their Revenue Streams.” Higher Education 50 (3): 387-411.

De Zilwa, D. 2010. Academic Units in a Complex, Changing World: Adaptation and Resistance. Dordrecht: Springer.

Diogo, S. 2015. "Same Challenges, Different Processes: Perceptions on Governance Changes in Portuguese and Finnish Higher Education.” European Journal of Higher Education 5 (2): 211225.

Elkin, G., J. Farnsworth, and A. Templer. 2008. "Strategy and the Internationalisation of Universities.” International Journal of Educational Management 22 (3): 239-250. 
Fahey, L., and H. K. Christensen. 1986. "Evaluating the Research on Strategy Content.” In 1986 Yearly Review of Management of the Journal of Management, edited by J.G. Hunt, and J.D. Blair, 167-183.

Galbraith, C., and D. Schendel. 1983. “An Empirical Analysis of Strategy Types.” Strategic Management Journal 4 (2): 153-173.

Hambrick, D. C. 1984. "Taxonomic Approaches to Studying Strategy: Some Conceptual and Methodological Issues.” Journal of Management 10 (1): 27-42.

Hardy, C. 1991. “Configuration and Strategy Making in Universities: Broadening the Scope.” The Journal of Higher Education 62 (4): 363-393.

Hawes, J. M., and W. F. Crittenden. 1984. “A Taxonomy of Competitive Retailing Strategies.” Strategic Management Journal 5 (3): 275-287.

Hemsley-Brown, J., and I. Oplatka. 2006. "Universities in a Competitive Global Marketplace: A Systematic Review of the Literature on Higher Education Marketing.” International Journal of Public Sector Management 19 (4): 316-338.

Hofer, C. W. 1975. “Toward a Contingency Theory of Business Strategy.” Academy of Management Journal 18 (4): 784-810.

Ivy, J. 2001. "Higher Education Institution Image: A Correspondence Analysis Approach.” International Journal of Educational Management 15 (6): 276-282.

Jarzabkowski, P. 2008. “Shaping Strategy as a Structuration Process.” Academy of Management Journal 51 (4): 621-650.

Jarzabkowski, P., and D. C. Wilson. 2002. “Top Teams and Strategy in a UK University.” Journal of Management Studies 39 (3): 355-381.

Kauppinen, I., and T. Kaidesoja. 2014. “A Shift towards Academic Capitalism in Finland.” Higher Education Policy 27 (1): 23-41.

Keller, G. 1983. Academic Strategy: The Management Revolution in American Higher Education. Baltimore: The Johns Hopkins University Press. 
Koryakina, T., C. S. Sarrico, and P. N. Teixeira. 2015. "Third Mission Activities: University Managers’ Perceptions on Existing Barriers.” European Journal of Higher Education 5 (3): 316330.

Kotler, P., and P. E. Murphy. 1981. “Strategic Planning for Higher Education.” The Journal of Higher Education 52 (5): 470-489.

Kruskal, J. B., and M. Wish. 1978. Multidimensional Scaling. Beverly Hills, CA: Sage Publications.

Marginson, S. 2012. “Korkeakoululaitos omaehtoisena ja yhteiskunnallisena instituutiona: julkisen ja yksityisen uudelleen arviointia.” In Kannattaako korkeakoulutus?, edited by H. Aittola, and T. Saarinen. University of Jyväskylä, 19-39.

Miles, R., and C. Snow. 1978. Organizational Strategy, Structure, and Process. New York: McGraw-Hill.

Mintzberg, H., and J. Rose. 2003. "Strategic Management Upside Down: Tracking Strategies at McGill University from 1829 to 1980.” Canadian Journal of Administrative Sciences 20 (4): 270290.

Montgomery, C. A., B. Wernerfelt, and S. Balakrishnan. 1989. "Strategy Content and the Research Process: A Critique and Commentary.” Strategic Management Journal 10 (2): 189-197.

Morphew, C. C., and M. Hartley. 2006. "Mission Statements: A Thematic Analysis of Rhetoric across Institutional Type.” The Journal of Higher Education 77 (3): 456-471.

Mouwen, K. 2000. "Strategy, Structure and Culture of the Hybrid University: Towards the University of the $21^{\text {st }}$ Century.” Tertiary Education and Management 6 (1): 47-56.

Porter, M. E. 1980. Competitive Strategy. New York: Free Press.

Rinne, R. 2004. "Searching for the Rainbow: Changing the Course of Finnish Higher Education.” In Reforming Higher Education in the Nordic Countries: Studies of Change in Denmark, Finland, Iceland, Norway and Sweden, edited by I. Fägerlind, and G. Strömqvist. Paris: UNESCO and International Institute for Educational Planning, 89-135.

Rolfe, H. 2003. "University Strategy in an Age of Uncertainty: The Effect of Higher Education Funding on Old and New Universities.” Higher Education Quarterly 57 (1): 24-47. 
Rowley, D. J., H. D. Lujan, and M. Dolence. 1997. Strategic Change in Colleges and Universities: Planning to Survive and Prosper. San Francisco: Jossey-Bass Publishers.

Shattock, M. 2000. "Strategic Management in European Universities in an Age of Increasing Institutional Self Reliance.” Tertiary Education and Management, 6 (2), 93-104.

Shirley, R. C. 1983. "Identifying the Levels of Strategy for a College or University.” Long Range Planning 16 (3): 92-98.

Tirronen, J. 2014. “Suomalaisten yliopistojen Strateginen johtaminen.” Hallinnon Tutkimus 33 (1): 70-77.

Treacy, D. W., and F. Wiersema. 1993. "Customer Intimacy and Other Value Disciplines.” Harvard Business Review Jan-Feb: 84-93.

Ursin, J., H. Aittola, C. Henderson, and J. Välimaa. 2010. “Is Education getting lost in University Mergers?” Tertiary Education and Management, 16 (4), 327-340.

Ursin, J., and J. Välimaa. 2012. “Korkeakoulu-uudistusten dynamiikka.” Kasvatus, 5, 547-549.

Vancil, R. F., and P. Lorange. 1975. "Strategic Planning in Diversified Companies.” Harvard Business Review Jan-Feb: 81-90.

Wyrwa, J. 2012. "The Design and the Implementation of the Development Strategy at Public Higher Education Institutions.” Management, 16 (2), 343-360. 


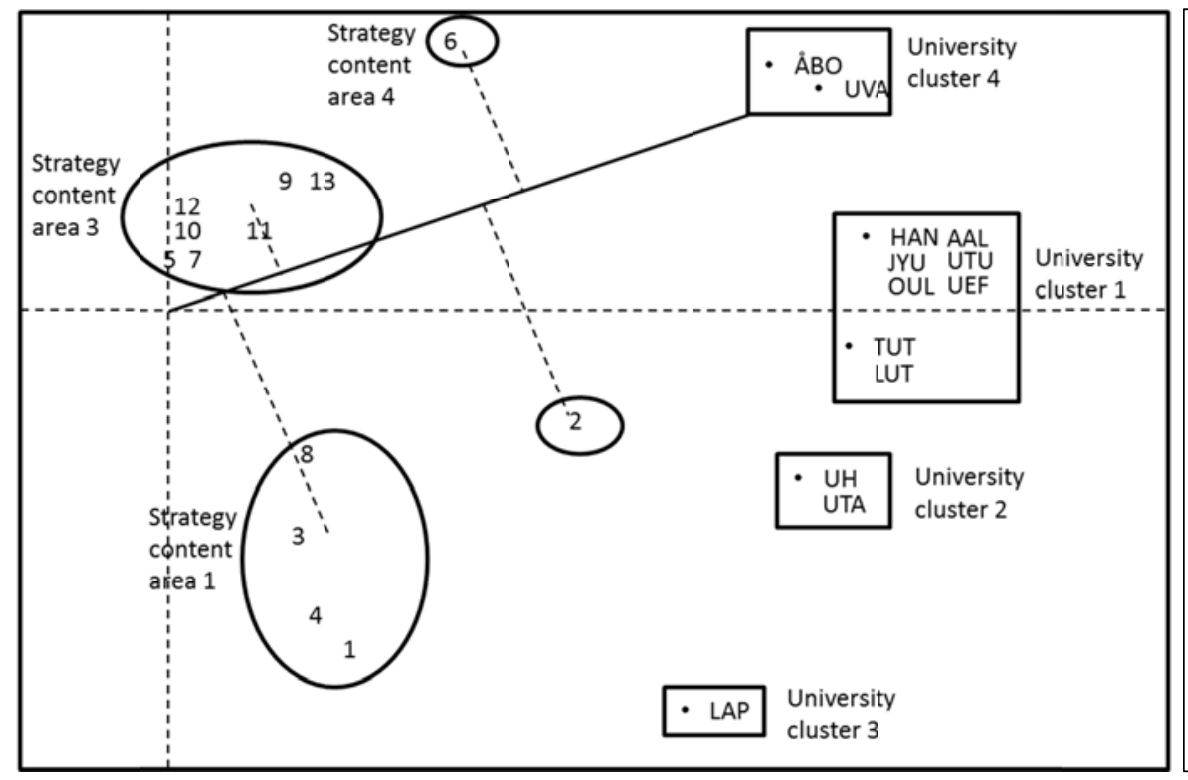

University codes

AAL Aalto University

UH University of Helsinki

UEF University of Eastern Finland

JYU University of Jyväskylä

LAP University of Lapland

LUT Lappeenranta University of Technology

OUL University of Oulu

HAN Hanken School of Economics

TUT Tampere University of Technology

UTA University of Tampere

UTU University of Turku

UVA University of Vaasa

ÅBO Åbo Akademi University

Keyword cluster codes and strategy content areas

1 Society, societal impact, responsibility

3 Values, ethics, integrity, equality

4 Cross-disciplinarity, scientific versatility

8 Brand, reputation, marketing, communications

2 International(ism), international impact/orientation, multicultural(ism)

5 Personnel recruitment/planning, attractive employer

7 Economy, effectiveness, financial planning/reporting

9 Working environment, research and teaching infrastructure, facilities

10 Student recruitment

11 Well-being, participation, community spirit

12 Tenure track, mobility, researcher exchange

13 New knowledge, innovation(s), scientific impact

6 Network(ing), partnerships, alliances

\section{Strategy content area 1:}

Diverse, ethical, and valued

member of society

\section{Strategy content area 2:}

Internationalism

\section{Strategy content area 3:}

Economy and internal

processes

\section{Strategy content area 4:}

Networking

Figure 1. The visual mapping of strategy content areas and university clusters.

(Produced by the author(s) by combining the results of MDS and cluster analysis.)

Note: The order in which the projections from the strategy content areas (the dotted lines) cross the shortest distance from the university cluster to the origin (the solid line), is the order in which the university cluster in question emphasises the content areas. One such order is marked as an example. 
Table 1. The results of ANOVA testing the differences of content areas between the four university clusters.

ANOVA

\begin{tabular}{|c|c|c|c|c|c|c|}
\hline & & Sum of Squares & df & Mean Square & $\mathrm{F}$ & Sig. \\
\hline $\begin{array}{l}\text { Diverse, ethical, and valued } \\
\text { member of society }\end{array}$ & $\begin{array}{l}\text { Between Groups } \\
\text { Within Groups } \\
\text { Total }\end{array}$ & $\begin{array}{r}61,960 \\
9,117 \\
71,077 \\
\end{array}$ & $\begin{array}{r}3 \\
9 \\
12 \\
\end{array}$ & $\begin{array}{r}20,653 \\
1,013\end{array}$ & 20,388 & ,000 \\
\hline Internationalism & $\begin{array}{l}\text { Between Groups } \\
\text { Within Groups } \\
\text { Total }\end{array}$ & $\begin{array}{r}62,317 \\
219,375 \\
281,692\end{array}$ & $\begin{array}{r}3 \\
9 \\
12 \\
\end{array}$ & $\begin{array}{l}20,772 \\
24,375\end{array}$ & ,852 &, 500 \\
\hline $\begin{array}{l}\text { Economy and internal } \\
\text { processes }\end{array}$ & $\begin{array}{l}\text { Between Groups } \\
\text { Within Groups } \\
\text { Total }\end{array}$ & $\begin{array}{r}13,097 \\
5,092 \\
18,188 \\
\end{array}$ & $\begin{array}{r}3 \\
9 \\
12 \\
\end{array}$ & $\begin{array}{r}4,366 \\
, 566\end{array}$ & 7,716 & ,007 \\
\hline Networking & $\begin{array}{l}\text { Between Groups } \\
\text { Within Groups } \\
\text { Total }\end{array}$ & $\begin{array}{r}150,269 \\
52,500 \\
202,769\end{array}$ & $\begin{array}{r}3 \\
9 \\
12\end{array}$ & $\begin{array}{r}50,090 \\
5,833\end{array}$ & 8,587 & ,005 \\
\hline
\end{tabular}

